\title{
Cistitis enfisematosa
}

\author{
Emphysematous cystitis
}

\section{CASE REPORT}

A self-employed 76-year-old-woman had a personal history of type 2 diabetes mellitus, arterial hypertension, dyslipidemia, and ischemic heart disease (acute myocardial infarction in 2005). She went to the emergency department due to diffuse abdominal pain, vomiting and dysuria with 2 days of evolution. Abdomen was soft and painful to deep palpation in the lower quadrants and suprapubic region. Laboratory test showed leukocytosis and CPR 152 $\mathrm{mg} / \mathrm{dL}$. Urine revealed leukocyturia and nitrites. Urinary culture revealed Escherichia coli. Abdominal - pelvic CT scan was performed, describing a poorly filled bladder with multiple gas bubbles, apparently including in its wall, compatible with emphysematous cystitis (Figures 1, 2).

Emphysematous cystitis (EC) was described by Bailey in 1961 in an autopsy. It is a rare complication of urinary tract infections caused by gas-producing bacteria. Most cases are caused by Escherichia coli or Klebsiella pneumoniae. Other common pathogens include Enterobacteria, Staphylococcus aureus, Proteus mirabilis, Pseudomonas aeruginosa, Streptococcus and fungi such as Candida. ${ }^{1}$ Mostly affects women over 60 years $^{2}$ with diabetes mellitus as main risk factor. Also, anatomical malformations, obstructive uropathies, immunosuppression, recurrent urinary infections and neurogenic bladder are described with a high link to this entity ${ }^{3}$. The main symptom (up to $80 \%$ of the cases) is abdominal pain. ${ }^{4}$ The diagnosis is made through an imaging exam due to the presence of air inside the bladder wall. ${ }^{1}$

\section{REFERENCES}

1. Ho MP, Chou AH, Wu YH, Tsai KC. Emphysematous cystitis in an elderly diabetic patient. Geriatr Gerontol Int. 2017;17(6):1027-1028.

2. Aramburu-López A, Ramos-Ugidos A et al. Cistitis Enfisematosa: caso clínico y breve revisión. Rev. Arg. De Urol. 2010, 75(3):164-6.

3. Cleves, DMC el al. Cistitis enfisematosa: Abordaje clínico y terapéutico. Urol colomb. 2016, 25 (1): p.46-49.

4. Iqbal N, Shah ARM, Saif UB, Hasan A, lqbal MW, Ali M. Emphysematous Cystitis in a NonDiabetic Male. J Coll Physicians Surg Pak. 2018;28(6):496-497.

Palabras clave: infecciones del tracto urinario, cistitis, diabetes mellitus Keywords: urinary tract infections, cystitis, diabetes mellitus
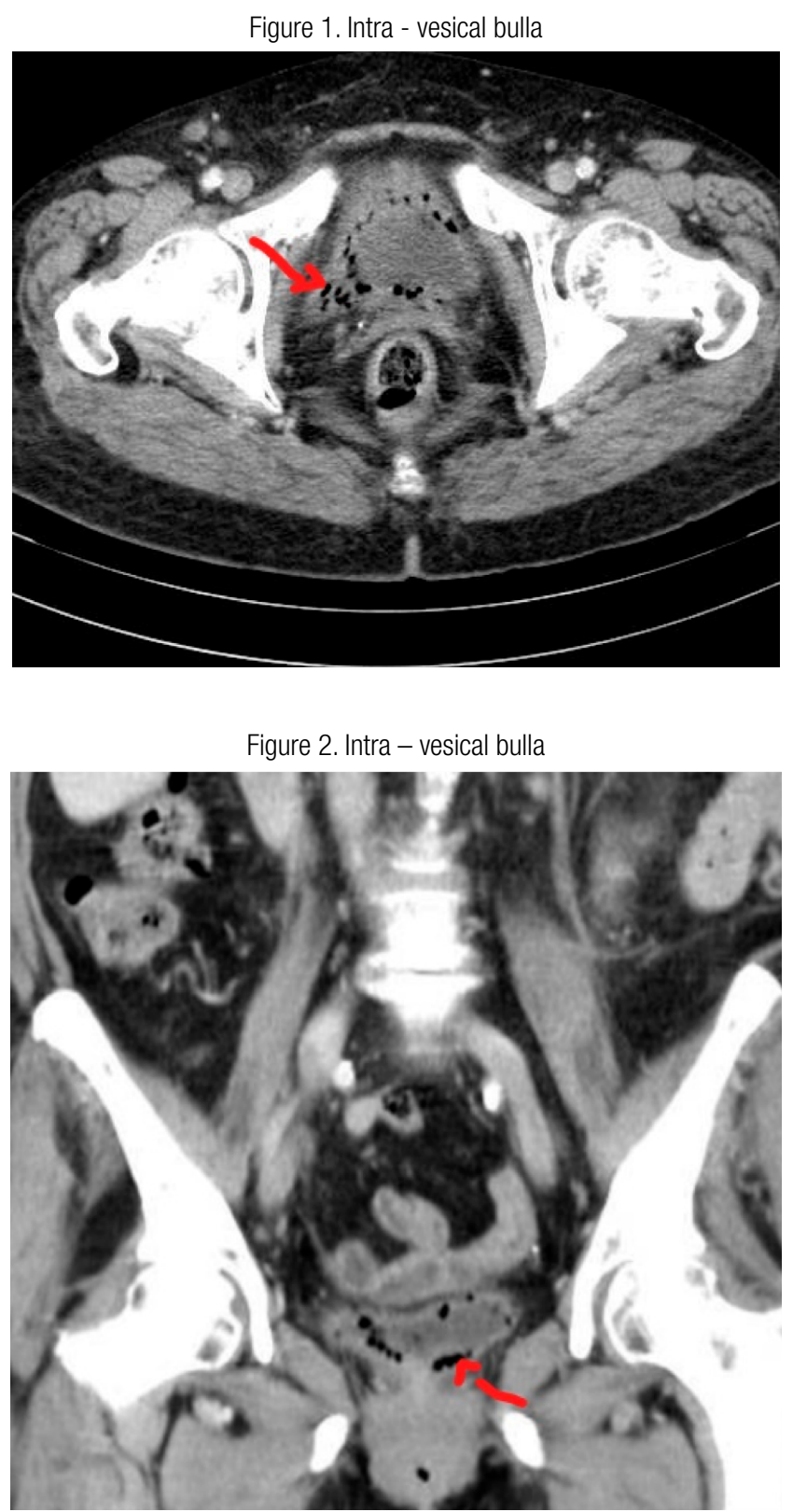

\section{Francisco Gomes, Mariana Almeida, Ruth Feio, Carina Ramalho}

Serviço de Medicina Interna do Centro Hospitalar do Barreiro-Montijo

Correspondencia: mandjay82@gmail.com

Cómo citar este artículo: Gomes F, Almeida M, Feio R, Ramalho C

Cistitis enfisematosa. Galicia Clin 2021; 82-3: 178

Recibido: 22/9/2020; Aceptado: 21/1/2021 // https://doi.org/10.22546/62/2376 